\title{
Appraising city-scale pollution monitoring capabilities of multi-satellite datasets using portable pollutant monitors
}

\author{
Yahaya A. Aliyu ${ }^{a, c,}{ }^{*}$, Joel O. Botai ${ }^{\text {ba }}$ \\ ${ }^{a}$ Department of Geography, Geoinformatics and Meteorology, University of Pretoria, Pretoria-0002, \\ South Africa \\ ${ }^{b}$ South African Weather Service, 442 Rigel Avenue South, Erasmusrand, Pretoria-0001, South Africa \\ ${ }^{c}$ Department of Geomatics, Ahmadu Bello University, Zaria, Kaduna-810282, Nigeria
}

\begin{abstract}
The retrieval characteristics for a city-scale satellite experiment was explored over a Nigerian city. The study evaluated carbon monoxide and aerosol contents in the city atmosphere. We utilized the MSA Altair 5x gas detector and CW-HAT200 particulate counter to investigate the city-scale monitoring capabilities of satellite pollution observing instruments; atmospheric infrared sounder (AIRS), measurement of pollution in the troposphere (MOPITT), moderate resolution imaging spectroradiometer (MODIS), multiangle imaging spectroradiometer (MISR) and ozone monitoring instrument (OMI). To achieve this, we employed the Kriging interpolation technique to collocate the satellite pollutant estimations over 19 ground sample sites for the period of 2015 - 2016. The portable pollutant devices were validated using the WHO air filter sampling model. To determine the city-scale performance of the satellite datasets, performance indicators: correlation coefficient, model efficiency, reliability index and root mean square error, were adopted as measures. The comparative analysis revealed that MOPITT carbon monoxide (CO) and MODIS aerosol optical depth (AOD) estimates are the appropriate satellite measurements for ground equivalents in Zaria, Nigeria. Our findings were within the acceptable limits of similar studies that utilized reference stations. In conclusion, this study offers direction to Nigeria's air quality policy organizers about available alternative air pollution measurements for mitigating air quality effects within its limited resource environment.
\end{abstract}

Keywords: Nigeria; Air pollution; Portable monitors; Satellite pollution estimates

\section{Introduction}

Air quality is undoubtedly a key subject of public concern (Gozzi et al., 2016). Petroleum derivatives and biomass consumption are the major sources of air pollution in developing cities and have been linked to unfriendly respiratory impacts (Marais et al., 2014). Exposure to air pollutants is increasing respiratory and cardiovascular morbidity and mortality (2.8 million deaths), with developing countries still experiencing the worst air pollution (WHO, 2016). With over a decade of global awareness on air pollution, studies are still reporting the effects of criteria pollutants on the human cardiovascular and respiratory systems (Ghozikali et al., 2015; Miri et al., 2016; Ren et al., 2017).

Rapid economic development coupled with scarce administrative policies within the African continent is leading to an increased level of air pollution, thus putting the wellbeing of its major population at risk (Marais and Chance, 2015). In Africa, studies on surface air 
pollution monitoring are insufficient, with only a few nations having established environmental procedures. South Africa is the only African country that appears to have established well-defined standards and a comprehensive monitoring network (Kgabi, 2014; Hersey et al., 2015).

Nigeria is Africa's most populated country (182 million people as at 2015) and also the largest economy, recently surpassing South Africa (The Economist, 2017; UN, 2017). Nigeria's rapid growth stimulates a variety of environmental worries, most especially air quality. Outdoor air pollution is majorly worsened by inept automobiles, unsystematic road structure leading to traffic obstruction, dependence on power generating sets by commercial outlets due to poor electricity infrastructure and congested road side activities (Adewunmi et al., 2015; Orogade et al., 2016). The measurements of outdoor pollutants are essential for human exposure awareness (Duvall et al., 2012; Bereznicki and Kamal, 2013).

Since urban air pollution undergoes several processes which generates its spatial variable concentrations, a network of pollution station units can be employed to predict concentrations at unmeasured locations and also effectively monitor urban air pollution (Kanaroglou et al., 2005; Adams et al., 2012; Dash, 2016). The density of an urban environment combined with natural variability and unpredictable anthropogenic emission sources, compels for the constant appraisal of pollution models by means of up-to-date datasets (Neophytou et al., 2011).

Low-cost pollutant monitors are getting extra attention in the area of air pollution monitoring, when compared with established reference devices (Kumar et al., 2015). The majority of the lower cost sensors is robustly designed using micro-electro-mechanical techniques and energy efficient sensor circuits. This makes them cost effective, light-weight and compact, thus consuming minimum power for detecting selected toxic gases and particulates in any industrialized environment (Mead et al., 2013). Their user-friendliness enables efficient near real-time resolution data acquisition, thus allowing for larger spatial coverage especially in remote/developing areas (Snyder et al., 2013). The availability of portable pollution monitoring detectors has considerably increased the possibility of identifying pollution hot spots, enriching air pollution maps, evaluating air quality policies and safeguarding public health (Engel-Cox et al., 2013; Gozzi et al., 2016). Cities across the globe are embracing the concept of portable test sites for gathering air quality variability and statistics for mitigation planning. Validated portable pollutant monitors can be adopted as ground-based retrieval stations, as they provide fast and transparent dissemination of observed dataset (Kumar et al., 2015; Gozzi et al., 2016). However, the challenges 
regarding the deployment of portable sensors for air pollution monitoring are their operational maintenance which in most cases eventually exceeds the actual cost of sensor. The operation maintenance comprises of device stability (such as sensor re-calibration, sensor/battery replacement), data management costs and operational longevity before replacement (Kumar et al., 2015).

Considerable achievements are still being realised in the area of space-based atmospheric pollution monitoring. Satellite pollution sensors have continued to show increased capability of observing chemical species at high 4-D resolutions that can be utilized for a wide range of environmental-friendly atmospheric related applications (Duncan et al., 2014; Zhang et al., 2016). While the particle satellite instruments measure the extinction of light to retrieve the chemical aerosols, the trace gas instruments measures the number density of the trace gas, all in a vertical column of air. This approach is also used to further estimate the chemical particles precisely under that column of air, as long as their movement and chemical conversion are minimally interfered with or compensated for (Streets et al., 2013). The advantage of satellite pollution data is its spatial and temporal coverage. This coverage serves as a surrogate for long-term regional air quality monitoring, as well as development of emission inventories (Engel-Cox et al., 2004; Schaap et al., 2009). The space-based pollution measurements are also being embraced as a distinctive resource for detecting air quality in regions with scarce ground-based information (Marais et al., 2014). The main challenge of satellite pollution instrument is its resolution at low-altitude. The measurements at low altitudes is perceived to be influenced by all kinds of atmospheric attenuations thus generating errors. For this reason, the satellite brochures continue to encourage researches to utilize the retrieved satellite datasets for surface test/validation procedures. Another familiar challenge of the satellite pollution instrument with limited resources establishments, is the technical know-how to access, process and accurate interpret the satellite pollution observational datasets (Duncan et al., 2014).

The dependence on portable monitors for air pollution monitoring is on the rise. There is also no record of Nigeria's air quality planners acknowledging the use of satellite pollution data resources. These are the motivation for the study. Thus we attempt to determine, the level of pollution measurements these satellite pollution estimates represent in a developing Nigerian city. It is on this basis, that this study pilots an approach for appraising city-scale monitoring capabilities of multi-satellite pollution datasets using ground-positioned, portable pollutant monitors. 


\section{Methods}

\subsection{Study Area}

Zaria metropolis is the centre for educational advancement for Northern part of Nigeria. The city is experiencing rapid population increase and urban sprawl thus deteriorating the air quality within the city. It covers an area of 296.036 square kilometres, with an estimated population of 938,521 . The topography is mainly flat at $670 \mathrm{~m}$ above mean sea level (Figure 1). The climate is categorized into dry (October - May) and wet (June - September) seasons. The seasons are distinguished by low temperature $\left(14.1^{\circ} \mathrm{C}\right)$ during the harmattan in January and peak temperature $\left(35.2^{\circ} \mathrm{C}\right)$ in April. The population is majorly Hausa speaking and dominant land use outside the built up area is sparse vegetation except during the rainy season. The area is drained by the Kubanni River and its many tributaries.

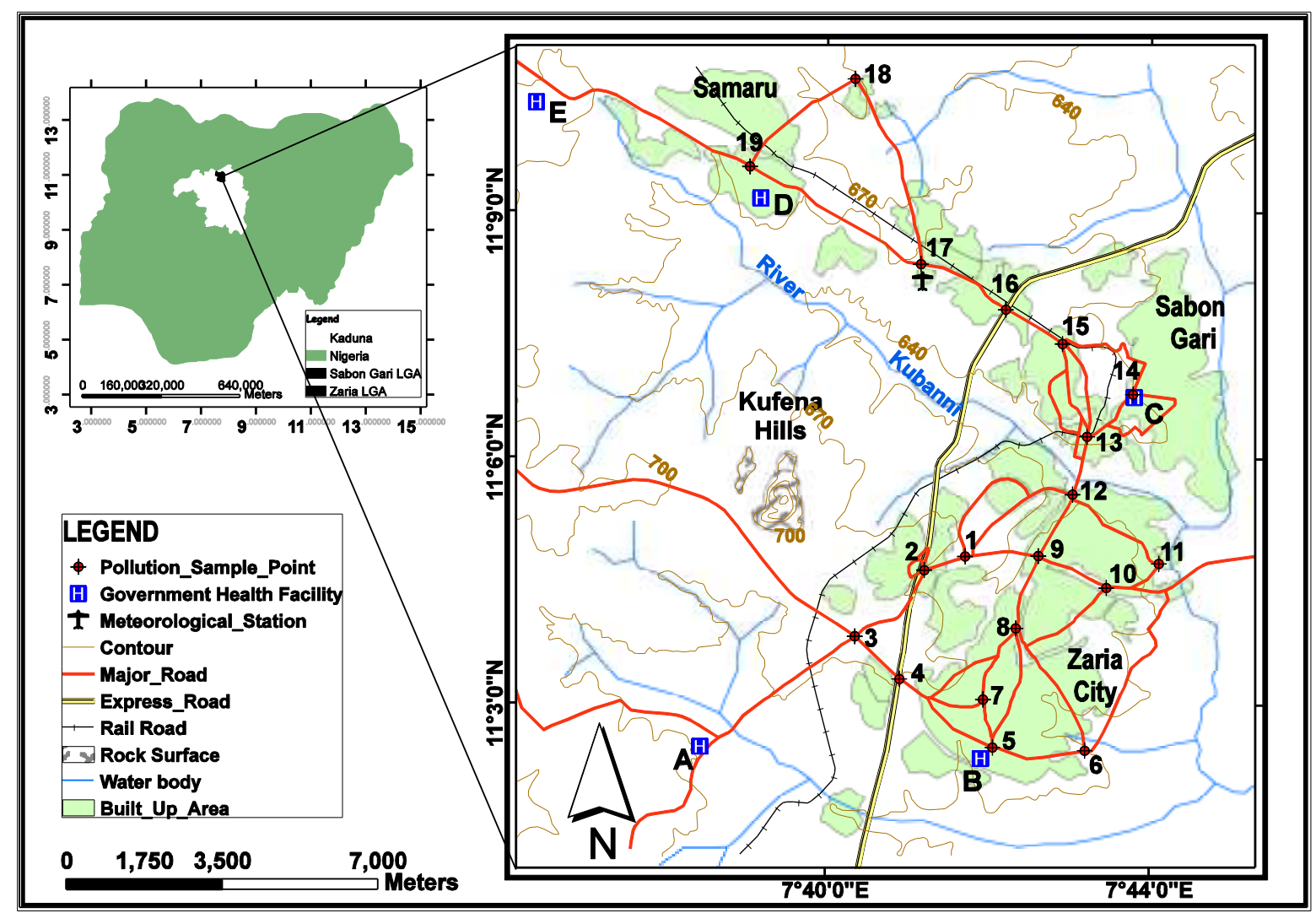

Figure 1. Study area displaying the Kufena hill, meteorological station and distribution of the 19 sample sites (Sites 3, 6 and 18 are control sites)

\subsection{Ground $\mathrm{CO}$ and $\mathrm{PM}$ datasets}

Figure 1 shows the distribution of the 19 sampling sites across study area. The sample sites were distributed to represent the majority of outdoor activities contributing to air pollution in the study area. 16 sites are located along major road intersections with dense 
population activity across residential and commercial settlements, while the remaining 3 control sites are positioned strategically at the outskirts of the city with minimal population activity. The control sites were adopted to serve as checks for results comparison. The portable monitoring devices are: the MSA Altair $5 \mathrm{x}$ which measures carbon monoxide (CO) in parts per million (ppm) and the CW-HAT200 which measures particulate matter $\left(\mathrm{PM}_{10}\right)$ in

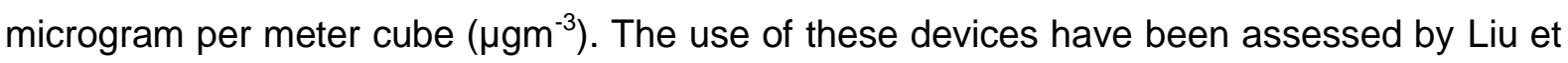
al., (2014): Mishra et al., (2015); Shibata et al., (2015). The devices were procured solely to collect ground level pollution concentrations of selected criteria pollutants across the study period (1 December 2015 - 30 November 2016).

Prior to the commencement of the ground sample collection using the portable monitors, the devices were validated using filter sampling papers to obtain total suspended particulates (TSP) at 2 sample test sites. This is based on the WHO air sampling model equation described in Efe and Efe (2008).

$$
\operatorname{TSP}\left(\mu g m^{-3}\right)=\frac{M_{S}-M_{O}}{V}
$$

Where TSP is the particulate matter, Mo is mass of filter paper prior to sampling, Ms is the mass filter paper after sampling, $V$ is the TSP volume. To determine the concentration $\left(\mu \mathrm{gm}^{-3}\right)$, the model equation 1 was divided by the sample time in hours.

102 filter samples were utilized to collect totally suspended particles (TSP) concurrently with the portable devices' measurements. Validation samples were obtained on Mondays, Wednesdays, Fridays and Sundays in the month of November 2015. One of the sample site had dense outdoor population activity and the other had minimal population activity (control site). Samples were collecting for morning, afternoon and evening periods. The portable devices and sample filters were positioned at the same $1.5 \mathrm{~m}$ above ground elevation. The obtained measurements at each site were weighted in order to obtain the 8-hr day-time average for outdoor activities over the 17 sampling days. Since our study is interested in air pollution resulting from outdoor population activities, we believed all pollutant emissions resulting from the population activities would strongly correlate against one another (Guo et al., 2017). It is for this reason that we utilized the filter samples from the two selected sample sites for validation of CW-HAT200 particulate counter and MSA Altair 5x multi-gas detector using $\mathrm{PM}_{10}$ and $\mathrm{CO}$ values respectively. The validation statistics showed that the correlation coefficient between the TSP concentrations from filter sampling and $\mathrm{PM}_{10} / \mathrm{CO}$ for the $\mathrm{CW}$ HAT200/MSA Altair 5x were highly significant. The correlation value (R) of TSP/PM 10 and TSP/CO were very strong across the two sites. The WHO procedure validated the reliability of the portable devices (Figure 2). 


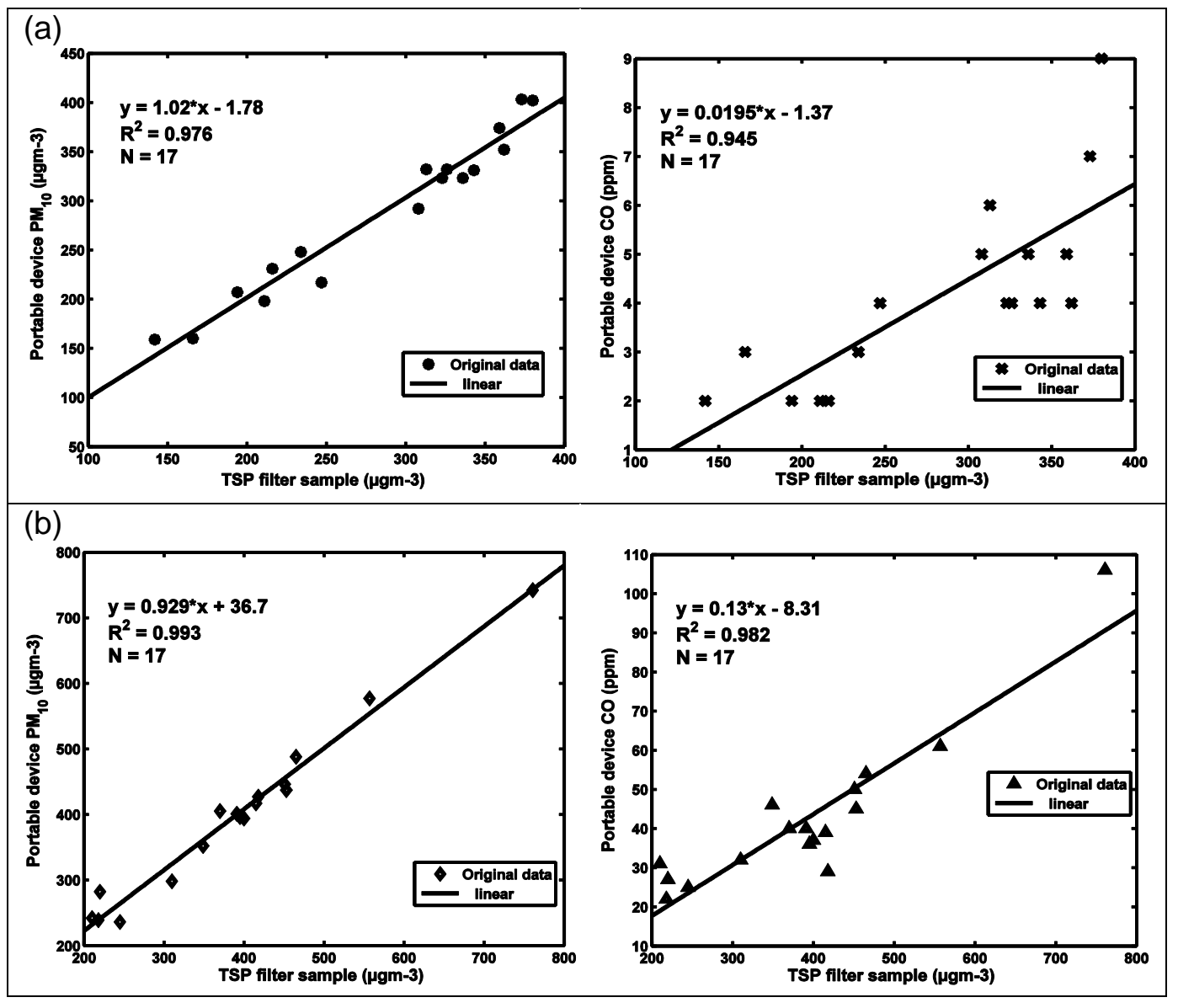

Figure 2. Linear regression showing validation of portable pollutant monitors and TSP samples using the WHO air sampling model. (a) Control site, (b) dense activity site

The criteria pollutants measured across the study site are: ground level carbon monoxide (GCO) and particulate matter with diameter less than 10 microns (GPM). The accuracy obtained was similar to those stated in the instrument configuration. To determine day-time averages, ground in-situ samples were collected daily across three epochs. The epochs are: peak morning (0730 - 0845 hrs), moderate afternoon (1300 - $1415 \mathrm{hrs})$ and peak evening (1700 - 1815 hrs) (Bell and Davis, 2001; Yazdi et al., 2015). A sample resolution time of 3 minutes was adopted per site. For each sampling, the highest perceived $\mathrm{CO}$ and $\mathrm{PM}_{10}$ concentrations were recorded based on instrument configuration. The values were weighted for the morning, afternoon and evening epochs respectively (Llanes, 2016). The samples were collected with devices positioned at 1.5 metres above ground level. Ground pollution samples (N) for GCO and GPM were collected for 339 out of the 366 days. A time-series plot for a control site (Site 6) and a seeming polluted site (Site 16) is displayed in Figure 3. The characteristics of the portable devices employed is highlighted in Table 1 and the descriptive statistics of recorded concentrations are shown in Table 2. 
a)

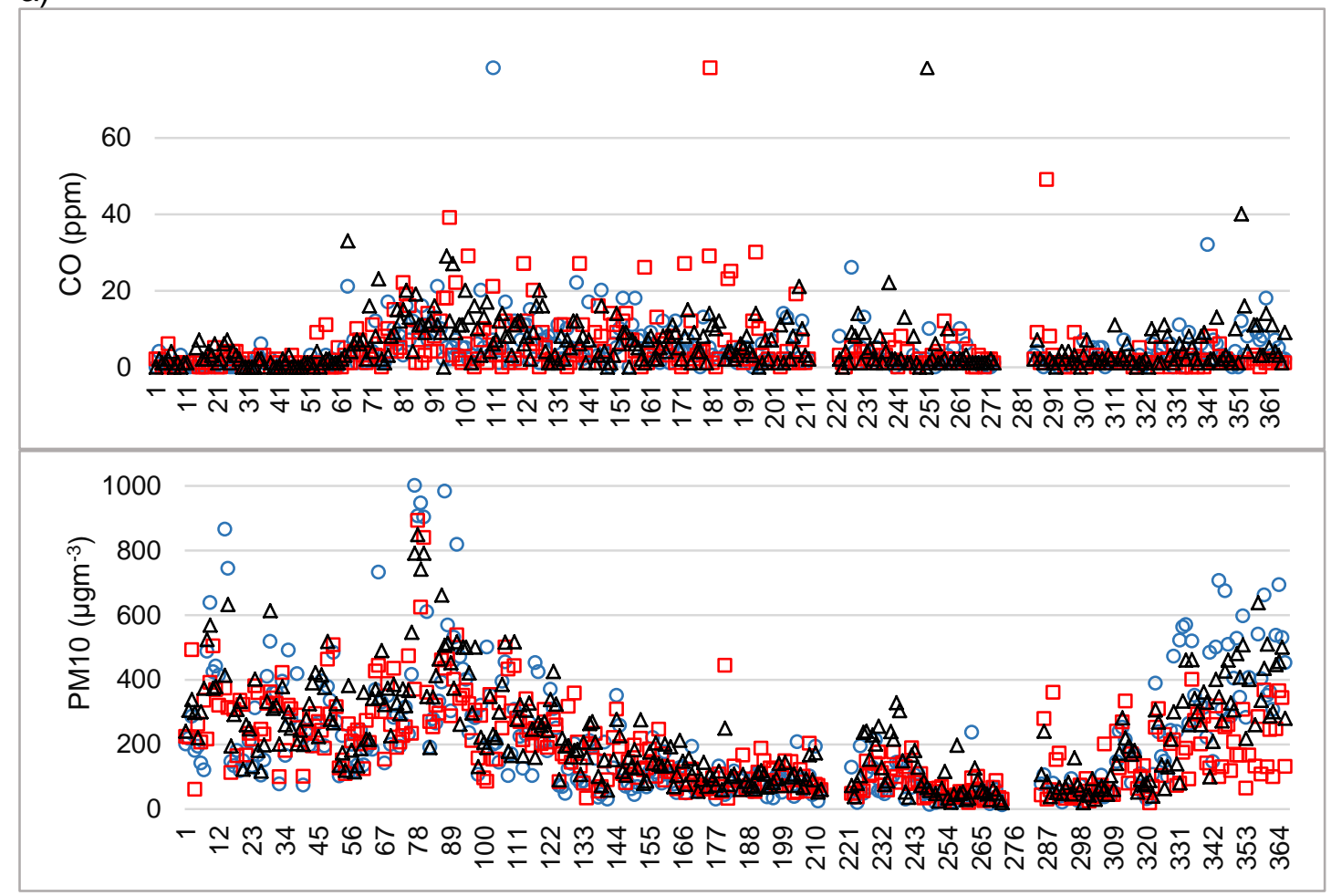

(b)

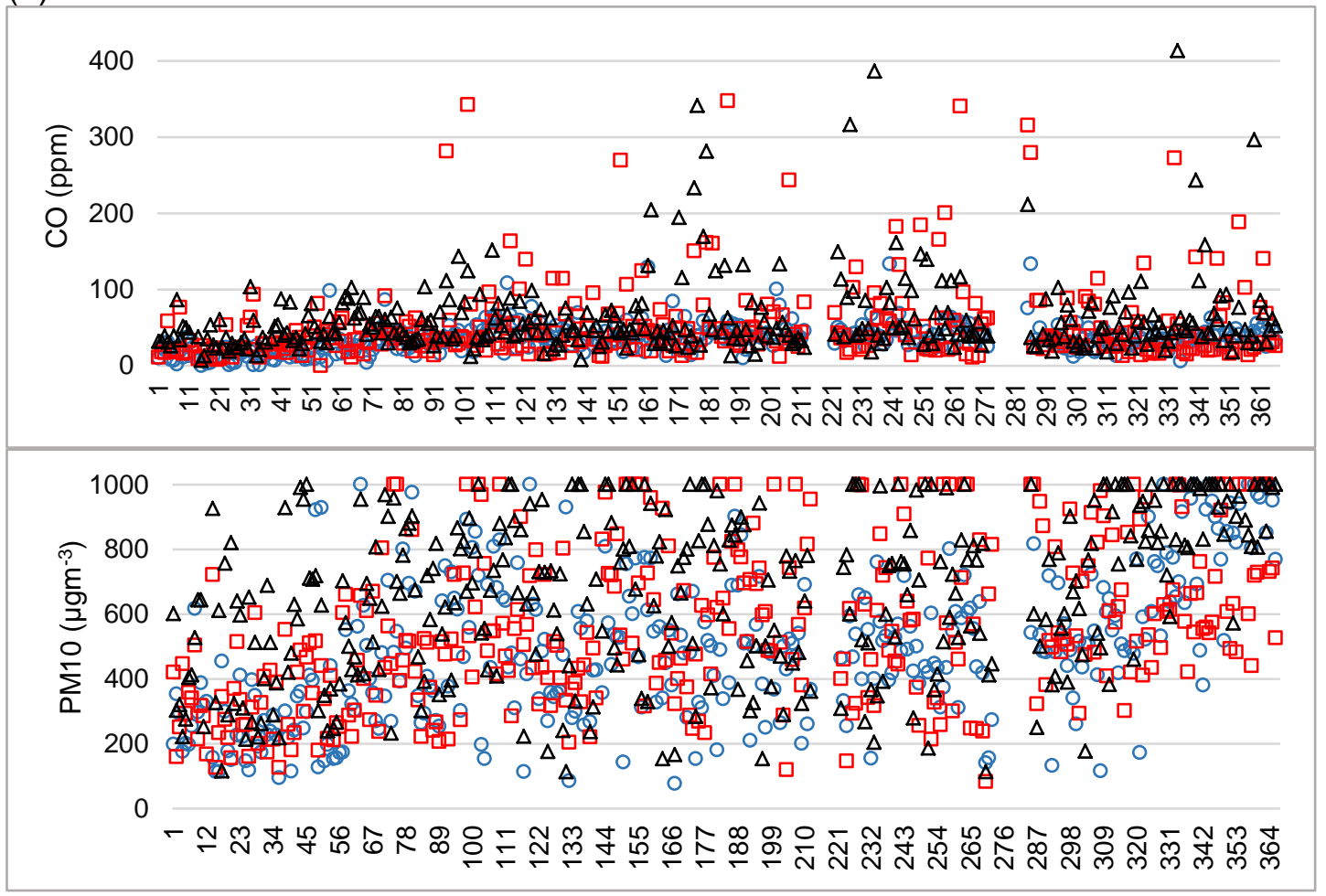

Figure 3. Times-series of the GCO and GPM concentrations (a) control site 6 (b) populated site 16, for the study period (1 December 2015 - 30 November 2016). Note that the blue, red and black scatter plots represents the morning, afternoon and evening sampling periods respectively. 
Table 1. Specifications of the portable pollutant monitors utilized for ground measurements

\begin{tabular}{|c|c|c|}
\hline Specifications & MSA Altair $5 x$ Gas Detector ${ }^{a}$ & $\begin{array}{l}\text { Chinaway CW-HAT200 Particulate } \\
\text { Counter }\end{array}$ \\
\hline Dimension $(\mathrm{cm})$ & $17(\mathrm{H}) \times 8.94(\mathrm{~W}) \times 4.88(\mathrm{D})$ & $18(\mathrm{H}) \times 9.3(\mathrm{~W}) \times 4.8(\mathrm{D})$ \\
\hline Weight (kg) & 0.45 & 0.60 \\
\hline Measuring method & $\begin{array}{l}\text { Internal pump; } \\
\text { Catalytic/electrochemical } \\
\text { sensor }\end{array}$ & Internal pump; laser light scattering \\
\hline Pollutant measured & $\begin{array}{l}\mathrm{CO} ; \mathrm{SO}_{2} ; \mathrm{H}_{2} \mathrm{~S} ; \mathrm{LEL} \\
\text { (Combustible) }\end{array}$ & $\mathrm{PM}_{2.5}, \mathrm{PM}_{10}$ \\
\hline Concentration Range & $\begin{array}{l}\mathrm{CO}(0-500 \mathrm{ppm}) \\
\mathrm{SO}_{2}(0-25 \mathrm{ppm}) \\
\mathrm{H}_{2} \mathrm{~S}(0-100 \mathrm{ppm}) \\
\mathrm{LEL}(0-100 \%)\end{array}$ & $\begin{array}{l}\mathrm{PM}_{2.5}\left(0-500 \mu \mathrm{gm}^{-3}\right) \\
\mathrm{PM}_{10}\left(0-1000 \mu \mathrm{gm}^{-3}\right)\end{array}$ \\
\hline Sample/Response & $\mathrm{CO}(15$ secs $)$ & $\mathrm{PM}_{2.5}$ (60 secs) \\
\hline Time & $\begin{array}{l}\mathrm{SO}_{2}(20 \text { secs }) \\
\mathrm{H}_{2} \mathrm{~S}(15 \text { secs })\end{array}$ & $\mathrm{PM}_{10}(60$ secs $)$ \\
\hline Accuracy & $\pm 10 \%$ of reading & $\pm 5 \%$ of reading \\
\hline $\begin{array}{l}\text { Operating } \\
\text { temperature }\end{array}$ & $-10^{\circ} \mathrm{C}$ to $40^{\circ} \mathrm{C}$ & $5^{\circ} \mathrm{C}$ to $45^{\circ} \mathrm{C}$ \\
\hline Operating humidity & $15-90 \% \mathrm{RH}$ & $<90 \% \mathrm{RH}$ \\
\hline Calibration Due & 6 months & 1 year \\
\hline Battery & Rechargeable lithium-ion & Rechargeable lithium-ion polymer \\
\hline Display & Monochrome & LCD \\
\hline Certification & CE, UL, CSA, IEC, IP & CE \\
\hline
\end{tabular}

.Instrument was re-calibrated during the data collection stage (January 2016 and June 2016). The calibration mixed gas specifications are: $\mathrm{CO}-50 \mathrm{ppm} ; \mathrm{SO}_{2}-5 \mathrm{ppm} ; \mathrm{H}_{2} \mathrm{~S}-15$ ppm; LEL - $58 \%$.

Table 2. Descriptive statistics of the GCO and GPM for the study area in $2015-2016$ ( $N=$ 19, 104)

\begin{tabular}{|c|c|c|c|c|}
\hline $\begin{array}{l}\text { Ground } \\
\text { Measurements }\end{array}$ & Period & Mean & Median & SD \\
\hline \multirow{5}{*}{ GCO (ppm) } & Whole Year & 29.2 & 23.0 & 28.3 \\
\hline & December-January-February & 20.3 & 16.0 & 20.1 \\
\hline & March-April-May & 34.3 & 28.0 & 30.2 \\
\hline & June-July-August & 34.2 & 27.0 & 32.2 \\
\hline & September-October-November & 28.0 & 23.0 & 27.1 \\
\hline \multirow{5}{*}{$\operatorname{GPM}\left(\mu \mathrm{gm}^{-3}\right)$} & Whole Year & 451.9 & 403.0 & 251.4 \\
\hline & December-January-February & 401.8 & 350.0 & 213.5 \\
\hline & March-April-May & 442.5 & 405.0 & 248.1 \\
\hline & June-July-August & 405.7 & 363.0 & 251.0 \\
\hline & September-October-November & 557.6 & 529.0 & 265.9 \\
\hline
\end{tabular}

\subsection{Satellite $C O$ and $A O D$ datasets}

The National Aeronautics and Space Administration (NASA) has a catalogue of datasets generated from several nadir-viewing earth observing system (EOS) instruments which include: atmospheric infrared sounder (AIRS); multi-angle imaging spectroradiometer (MISR); moderate resolution imaging spectroradiometer (MODIS); measurements of pollution in the troposphere (MOPITT) and ozone monitoring instrument (OMI) (Streets et al., 
2013). The NASA-funded exploration aims to enable researches trace, link and cite these data to the scientific literature (NASA, 2017).

Carbon monoxide is a gaseous pollutant that usually results from incomplete combustion of anthropogenic sources, or oxidation of hydrocarbons (Rinsland et al., 2006). $\mathrm{CO}$ retrievals are exceptional for detecting anthropogenic activities, assessing emissions, and resolving wind effect on emission sources (Fisher et al., 2010). NASA's EOS instrument records nadir measurements of $\mathrm{CO}$ at $4.6 \mu \mathrm{m}$ from low Earth orbit using varying retrieval algorithms: AIRS (McMillan et al., 2005) and MOPITT (Deeter et al., 2003). For the city-scale evaluation, the vertical mixing ratio for satellite $\mathrm{CO}$ estimates were utilized based on recommendation. The reason is that the AIRS CO total column is the integral over the entire atmospheric column (AskAirs, personal communication, 16 February 2016). The lowest altitude/pressure level for AIRS and MOPITT CO mixing ratios are $925 \mathrm{hPa}$ and $900 \mathrm{hPa}$ respectively. These pressure levels are a weighted average of a good portion of the lower and middle troposphere. Normally, the same altitude/pressure level should be adopted for consistency. However, the lowest collocating $\mathrm{CO}$ mixing ratio altitude between the AIRS and MOPITT sensor is $700 \mathrm{hPa}$. This pressure level is not good enough for comparison with ground level data (Marey et al. 2015).

Particulate matter is reported to adversely affect respiratory health of varying agegroups (Yoshizaki et al., 2017). The primary satellite parameter for PM is aerosol optical depth (AOD). AOD is the total extinction effects on the incident radiation after its atmospheric interaction with particulates of different dimensions (Liou, 2002). To evaluate $A O D$ and $P M$, available literature have indicated that, there is a linear relationship between these two quantities. This empirical approach is the most recognised for distinguishing PM concentration from satellite data, whereby the degree of prediction can be determined using the level of correlation between the in-situ PM measurement and corresponding satellite AOD, of equal variables (Schäfer et al., 2008; Yap and Hashim, 2013). A detailed data processing method for distinguishing AOD from PM is described in Filip and Stefan (2011). For the satellite AOD estimates used in this study, the MODIS ( $1 \mathrm{~km}$ resolution) and OMI $\left(13^{\star} 27 \mathrm{~km}\right.$ resolution) instruments provide daily global AOD coverage via recording of the Earth's spectral radiance. The MISR as well, delivers AOD information at $17.6 \mathrm{~km}$ resolution approximately twice a month.

\subsection{Satellite data parameter}

Level 3 data was adopted for the various satellite instruments. This is due to their geophysical parameters which have been averaged into longitude/latitude grid cells. The 
map coordinates are gridded from $-180.0^{\circ}$ to $+180.0^{\circ}$ across longitude and $-90.0^{\circ}$ to $+90.0^{\circ}$ across latitude (Tian et al., 2014). The NASA satellite data provides a global coverage of atmospheric pollution in Hierarchical Data Format-Earth Observing System (HDF-EOS) and Network Common Data Form (NetCDF) formats, which can be accessed using software such as Panoply (Vollmer, 2010). Users are encouraged to embrace the level 3 processing as every essential filters and rectifications have been effected (Streets et al., 2013). The NASA data acquisition portal also made provision for sub-setting locations and variables of interest.

A subset covering the study area was adopted using spatial boundary box of (7.0, 11.0, 12.0, 8.0) degrees for West, South, North and East respectively. The satellite data estimates were synchronized with the ground measurements using Kriging interpolation technique (Araki et al., 2015). The AIRS standard product and MOPITT (near and thermal infrared radiance) were utilized. The data variables used for this study are available on the NASA retrieval platform (https://reverb.echo.nasa.gov). Table 3 shows retrieval characteristics of the satellite instrument datasets adopted for the study.

Table 3. Retrieval characteristics of the selected NASA satellite instruments

\begin{tabular}{|c|c|c|c|c|c|}
\hline Instrument & Specie & Version & $\begin{array}{l}\text { Sample } \\
\text { size }\end{array}$ & URL & Variable \\
\hline AIRS & $\mathrm{CO}$ & 6 & 251 & $\begin{array}{l}\text { http://disc.sci.gsfc.n } \\
\text { asa.gov/SSW/\#key } \\
\text { words=AIRX3STD } \\
006\end{array}$ & $\begin{array}{l}\text { ascending_TqJoint:CO } \\
\text { _VMR_TqJ_A }\end{array}$ \\
\hline MOPITT & $\mathrm{CO}$ & 6 & 79 & $\begin{array}{l}\text { https://eosweb.larc. } \\
\text { nasa.gov/project/m } \\
\text { opitt/mop03j_table }\end{array}$ & $\begin{array}{l}\text { RetrievedCOMixingRat } \\
\text { ioProfileDay }\end{array}$ \\
\hline MODIS & AOD & 5.1 & 210 & $\begin{array}{l}\text { http://disc.sci.gsfc.n } \\
\text { asa.gov/SSW/\#key } \\
\text { words=MYD08_D3 } \\
5.1\end{array}$ & $\begin{array}{l}\text { Deep_Blue_Aerosol_O } \\
\text { ptical_Depth_Land_Me } \\
\text { an }\end{array}$ \\
\hline MISR & AOD & 4 & 47 & $\begin{array}{l}\text { https://eosweb.larc. } \\
\text { nasa.gov/project/mi } \\
\text { sr/misr_table }\end{array}$ & $\begin{array}{l}\text { Optical_depth_averag } \\
\text { e }\end{array}$ \\
\hline OMI & AOD & 3 & 143 & $\begin{array}{l}\text { http://disc.sci.gsfc.n } \\
\text { asa.gov/SSW/\#key } \\
\text { words=OMAEROe } \\
003\end{array}$ & $\begin{array}{l}\text { AerosolOpticalThickne } \\
\text { ssMW: Best Fit } \\
\text { Spectral Aerosol } \\
\text { Optical Thickness } \\
\text { derived with the Multi- } \\
\text { Wavelength method, } \\
\text { scaled by a factor } \\
1000\end{array}$ \\
\hline
\end{tabular}

To determine the city-scale performance of these satellite pollution datasets, four performance indicators; reliability index, correlation coefficient, root mean square error and model efficiency, were utilized. The indicators are described as follows: 
The Cronbach's alpha ( $\alpha)$ is an index of reliability $(R I)$ which reveals the internal consistency associated with the variation accounted for a test or scale. The internal consistency defines the extent to which all the items in an investigation are inter-related. The reliability should be determined before an investigation can be employed for research to ensure validity (Le Boennec and Salladarré, 2017). It is expressed as a number between 0 and 1 , with $\geq 0.7$ regarded as acceptable reliability coefficient. It is expressed in Equation 2 below.

$$
\alpha=\frac{N \cdot \bar{C}}{\bar{v}+(N-1) \cdot \bar{C}}
$$

$\mathrm{N}$ is the sample size; $\mathrm{c}$ average covariance between the observed ground level pollutants $\mathrm{O}_{i}$ (i.e., GCO and GPM) and the predicting $\mathrm{P}_{\mathrm{i}}$ (i.e., AIRS, MOPITT, MODIS, OMI and MISR) retrievals; $\bar{v}$ is the average variance

The Correlation coefficient $R$, is the measure of how intimate the statistical data are to the fitted line of regression. As expressed in equation 3 below, it is the correlation coefficient or anomaly correlation coefficient (ACC) (Jolliffe and Stephenson, 2012).

$$
\mathrm{R}=\left[\frac{\left.\sum_{i=1}^{n}\left(P_{i}-\bar{P}\right)\left(O_{i}-\bar{O}\right)\right)}{\left[\sum_{i=1}^{n}\left(P_{i}-\bar{P}\right)^{2} \times \sum_{i=1}^{n}\left(O_{i}-\bar{O}\right)^{2}\right]^{\frac{1}{2}}}\right]
$$

The Root Mean Square Error (RMSE) is the square root of the variance of the residuals which describes how close the observed pollution data points are, to modelled predicted values (Chai and Draxler, 2014). It is expressed in equation 4 below.

$$
\text { RMSE }=\sqrt{\frac{1}{n} \sum_{i=1}^{n}\left(O_{i}-P_{i}\right)^{2}}
$$

The Nash-Sutcliffe model efficient coefficient (NSE) is a statistic of fitness that evaluates how one model forecasts the other relative to the average of the observation between both, with values varying between 0 and 1 (McCuen et al., 2006). It is expressed by equation 5 .

$$
N S E=1-\frac{\sum_{i=1}^{n}\left(\text { Bias }_{i}\right)^{2}}{\sum_{i=1}^{n}\left(\mid\left(P_{i}-\bar{O} \mid\right)-\left(\mid\left(O_{i}-\bar{O} \mid\right)^{2}\right.\right.}
$$

$\mathrm{Oi}$ and $\mathrm{Pi}$ are respectively the time series of the observed ground level pollutants (i.e., $\mathrm{CO}$ and PM) and the predicting (i.e., AIRS, MOPITT, MODIS, OMI and MISR) retrievals. The average of 
the observed and predicted retrieval values are indicated by $O$ and $P$, respectively, and the number of observations is indicated by $N$.

The NSE and $R$, are unit-less prediction measures that are indicative of model fit. The model prediction performance is acceptable if the NSE and R, are respectively greater than 0.4 and 0.5 (Engel et al., 2007).

\section{Results}

This section discusses the results of the various satellite retrievals evaluation at diurnal and seasonal scales, with relation to the respective validated ground measurements (GCO and GPM). Table 4 highlights the number of collocating samples size between the satellite retrievals and ground measurements as well as collocating samples size between cosatellite retrievals for the study period.

Table 4. Collocation sample size of the satellite retrieved estimates with ground measurements

\begin{tabular}{ll|c|c|c|c|c}
\hline Indicators & Pollutants & Collocating Instruments & \multicolumn{3}{c}{ Seasons } \\
\hline & & & DJF & MAM & JJA & SON \\
\cline { 2 - 7 } & \multirow{3}{*}{ CO } & GCO-AIRS CO & 78 & 75 & 64 & 11 \\
\cline { 2 - 7 } & & GCO-MOPITT CO & 26 & 21 & 6 & 20 \\
& & AIRS CO-MOPITT CO & 26 & 21 & 8 & 2 \\
\cline { 2 - 7 } Sample size, $N$ & & GPM-OMI AOD & 40 & 40 & 8 & 19 \\
& \multirow{4}{*}{ PM (AOD) } & GPM-MODIS AOD & 82 & 70 & 23 & 12 \\
& & GPM-MISR AOD & 17 & 13 & 5 & 11 \\
& & OMI-MODIS AOD & 41 & 31 & 2 & 3 \\
& & OMI AOD-MISR AOD & 1 & 2 & - & 1 \\
& MODIS AOD-MISR AOD & 11 & 13 & 5 & 1 \\
\hline
\end{tabular}

3.1. Diurnal distribution of the satellite retrievals and ground measurements

The collocated diurnal averages of satellite retrievals (AIRS-MOPITT CO and MODISMISR-OMI AOD) were plotted respectively against GCO and GPM as shown in Figure 4. Our findings showed that the day-time 8-hour averaged samples from ground measurements were above the stipulated threshold (WHO, 2017) of $9 \mathrm{ppm}$ and $50 \mu \mathrm{gm}^{-3}$ for $\mathrm{CO}$ and $\mathrm{PM}_{10}$ respectively. For the GPM measurements, there was a sudden increase in GPM concentrations in late 2016. This is attributed to the commencement of intense construction works (drainage and road rehabilitation) by the Kaduna state government across the study area. For satellite retrieved pollutants, AIRS CO mixing ratio (ppb) and MOPITT CO vertical mixing ratio (ppbv) recorded CO peak values of 229.876 and 247.338 respectively (Figures $4 a$ and $b$ ), while MODIS AOD, MISR AOD and OMI AOD recorded 3.146, 1.135 and 5.817 (no units) respectively (Figure $4 \mathrm{c}$ ). This study notes that there was data breach from the 
NASA download portal for the satellite instruments AIRS CO data from 25 September 2016 and MODIS AOD data from 7 October 2016 to the end of study period (30 November 2016).

(a)

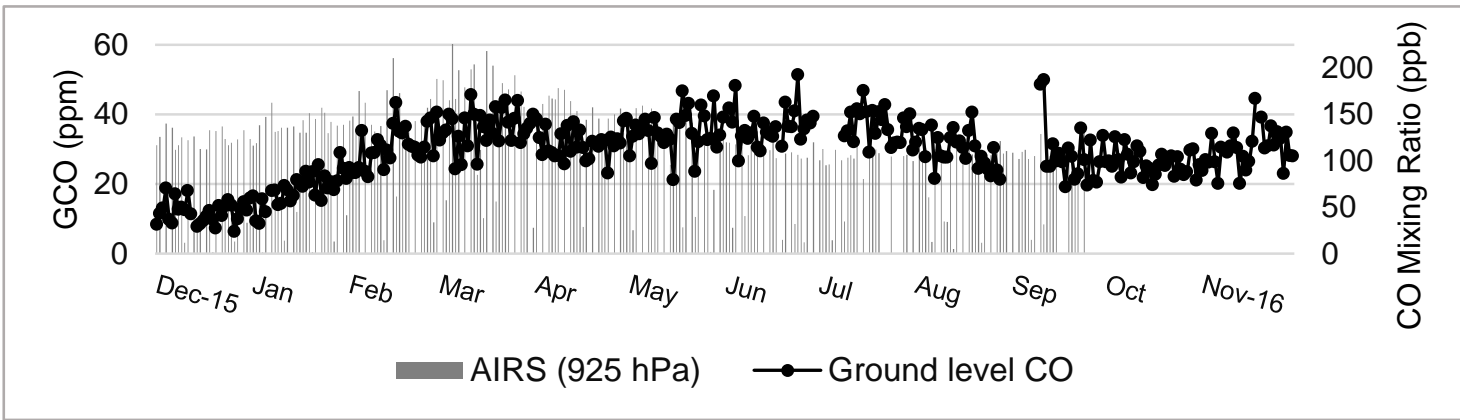

(b)

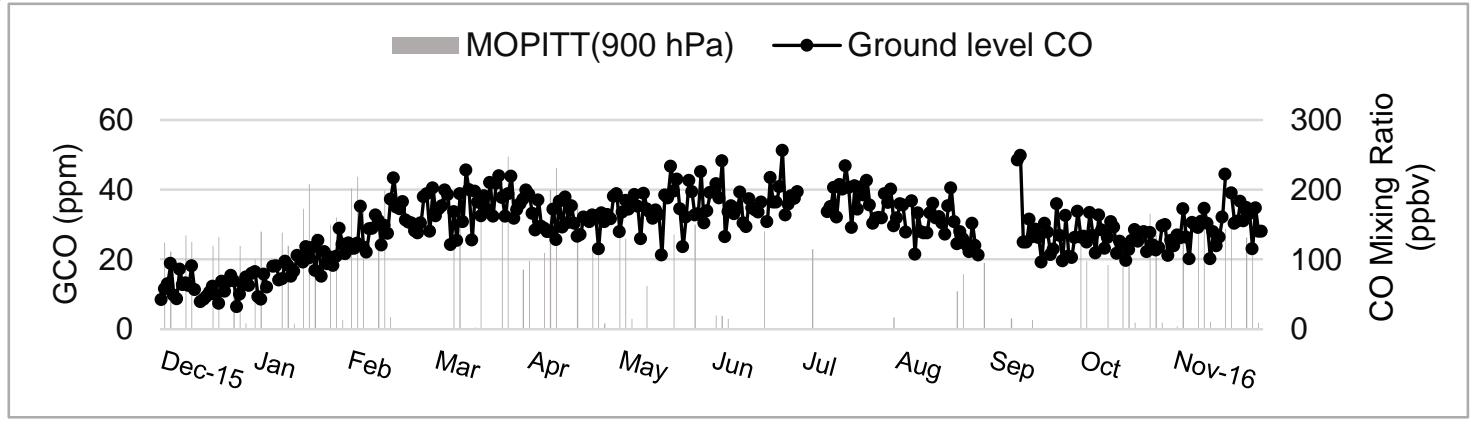

(c)

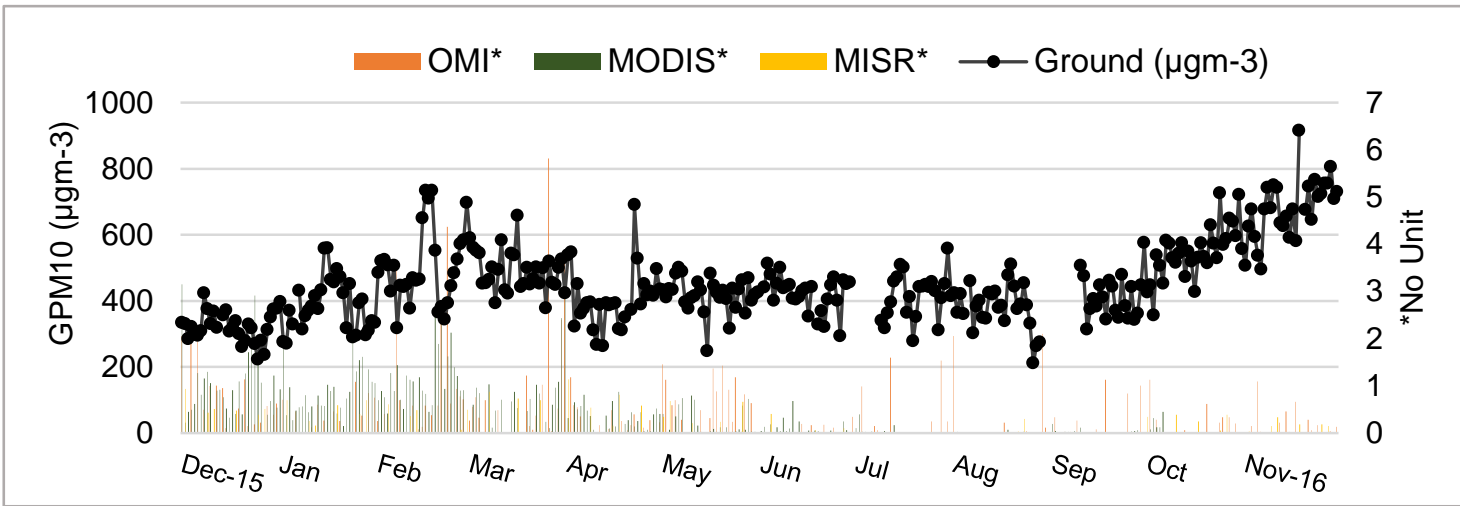

Figure 4. Collocating time series plots (a) GCO-AIRS CO (b) GCO-MOPITT CO (c) GPM MODIS-MISR-OMI AODs.

\subsection{Seasonal relationship of the satellite retrievals with ground measurements}

For analysis suitability, the seasonal pollution estimates of AIRS CO, MOPITT CO, MODIS AOD, MISR AOD and OMI AOD were harmonized (i.e. pairing of common days in 2015 and 2016) with the respective validated GCO and GPM measurements. The study period was also categorized into December-January-February (DJF); March-April-May (MAM); June-July-August (JJA); September-October-November (SON). Satellite retrievals were also harmonized against one another, to serve as check. Their statistical performance is displayed in Figure 5. 
(a) Dec-Jan-Feb

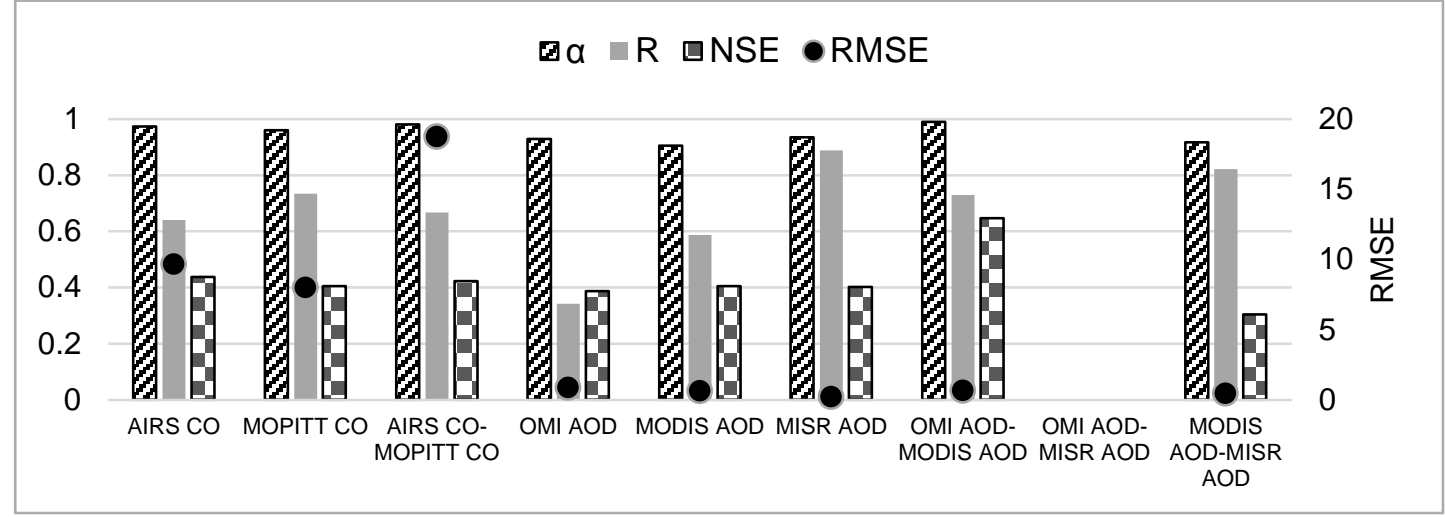

(b) Mar-Apr-May

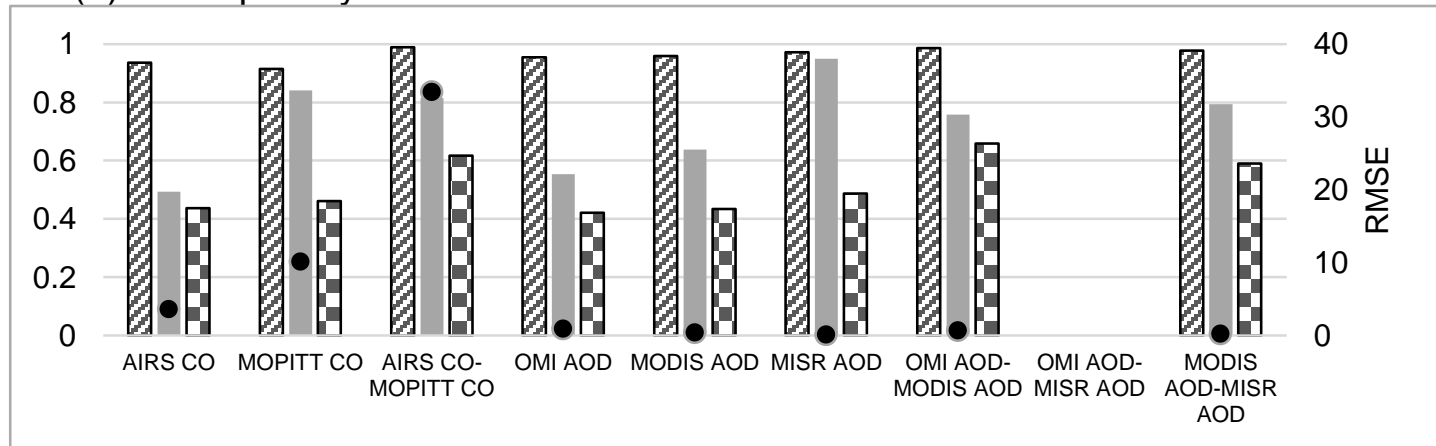

(c) Jun-Jul-Aug

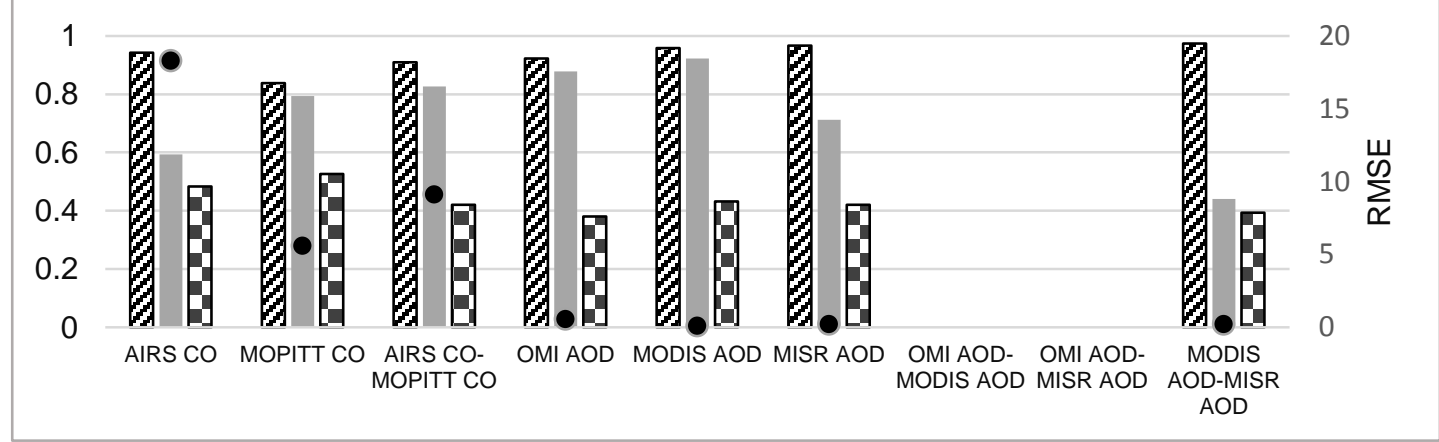

(d) Sep-Oct-Nov

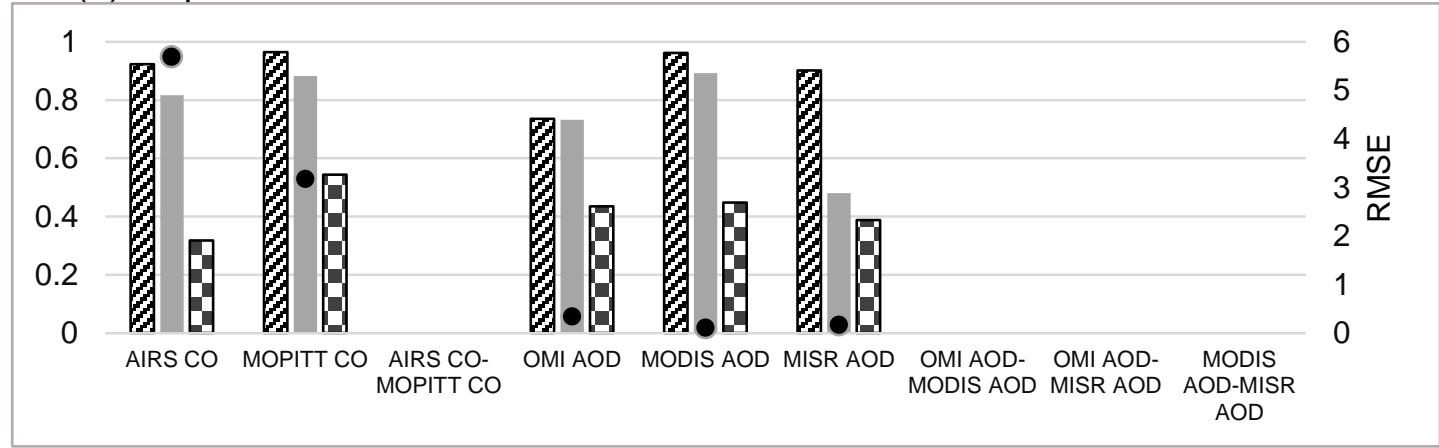

Figure 5. Seasonal performance of satellite retrieved estimates with collocating ground measurements. The $\alpha, R$ and NSE value ranges from $0-1$ (Left axis). Note that the collocating instruments that did not display any information, is due their collocating sample size data being less than 5 (See Table 4). 


\subsubsection{CO analysis}

The seasonal coefficients of reliability amongst synchronized retrieval instruments varied between $(0.923-0.973)$ and $(0.838$ - 0.964) for AIRS CO and MOPITT CO respectively. AIRS $\mathrm{CO}$ showed a higher $\mathrm{RI}$ which can be attributed to its higher paired measurement samples of 228 with GCO, compared to MOPITT CO's 73. Both models reliability coefficients were within acceptable limits. Accuracy measures for the satellite retrievals showed acceptable results of RMSE for AIRS CO (3.629 - 18.289) and MOPITT CO $(3.171$ - 10.171). The MOPITT CO showed a better correlation compared to the AIRS CO. The efficiency of the models as indicated by the NSE in Figure 5, displayed that both AIRS CO and MOPITT CO had acceptable values (>0.40) for all the season except for season SON where AIRS CO recorded 0.317. The correlation of paired data over the $2015-$ 2016 period yielded coefficient value for AIRS CO and MOPITT CO in the range of $(0.493-$ $0.814)$ and $(0.734-0.841)$ respectively. The reference AIRS CO - MOPITT CO model showed acceptable values for the four performance indicators except for the SON season, where paired common days was less than 5 (Table 4). The analysis revealed that the MOPITT CO product displayed the better performance and therefore, is deemed the better suited satellite $\mathrm{CO}$ measurement instrument for users in the Zaria. To further improve our findings on the MOPITT CO analysis, we compared the MOPITT CO surface variable (RetrievedCOSurfaceMixingRatioDay) with the GCO. Using the above listed performance measures, the results (Table 5) confirmed the performance of the MOPITT CO surface, as still, the well-matched satellite CO instrument for Zaria users.

Table 5. Seasonal performance of MOPITT CO surface estimates against validated GCO

\begin{tabular}{ccccccc}
\hline Pollutant & Collocating Instrument & Indicators & \multicolumn{4}{c}{ Seasons } \\
\hline & & & DJF & MAM & JJA & SON \\
\hline \multirow{4}{*}{ CO } & GCO/ & Sample size, $n$ & 26 & 21 & 6 & 20 \\
& MOPITT CO & $A$ & 0.972 & 0.970 & 0.914 & 0.975 \\
& Surface Mixing Ratio & RMSE & 7.997 & 9.113 & 6.162 & 3.005 \\
& & NSE & 0.417 & 0.450 & 0.462 & 0.520 \\
& & $R$ & 0.732 & 0.875 & 0.910 & 0.895 \\
\hline
\end{tabular}

Our evaluation of the MOPITT CO estimates for city-scale monitoring are similar to documented studies on comparison using validated ground measurements (Barret et al., 2003; Asatar and Nair, 2010; Zhang et al., 2016; Buchholz et al., 2017) and better than Sukitpaneenit and Oanh (2014) (Figure 6a). 
(a)

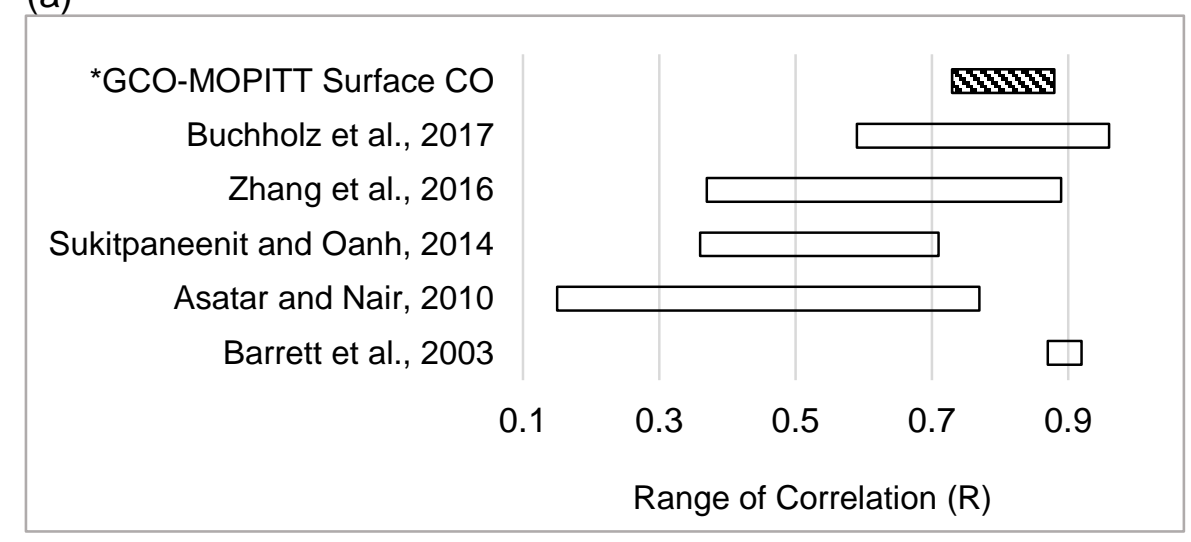

(b)

*GPM-MODIS AOD

Kong et al., 2016

Bibi et al., 2015

Sukitpaneenit and Oanh, 2014

Yap and Hashim, 2013

Filip and Stefan, 2011

Liu et al., 2007

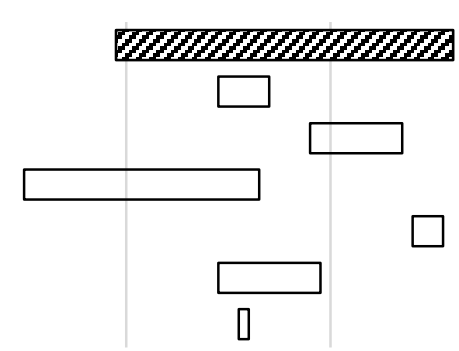

0.8
1

Range of Correlation (R)

Figure 6. Range of correlation coefficient obtained in comparison with similar literature (a) ground CO-MOPITT CO, (b) ground PM-MODIS AOD; $\left(^{*}\right)$ shaded bars - authors' findings

\subsubsection{AOD analysis}

In Figure 5, the reliability of the collocating satellite datasets across the seasons averaged $0.885,0.946$ and 0.944 for OMI AOD, MODIS AOD and MISR AOD respectively. These values were within acceptable limits. RMSE ranged from $0.094-0.937$, with MISR AOD recording the most precise of the three models. For model efficiency, the MODIS AOD averaged highest with 0.430 , followed by MISR AOD with 0.424 and finally OMI AOD with 0.406 . They were all within acceptable limits (NSE > 0.40). Correlating satellite retrievals with respective GPM, the model estimations $(R)$ varied from $(0.343-0.878),(0.587-0.922)$ and $(0.481$ - 0.950) for OMI AOD, MODIS AOD and MISR AOD respectively. On the average, the MISR AOD outpaced other comparatives in the DJF and MAM seasons. The performance reduced in the later part of 2016. This can be attributed to its reduced sample size during the JJA and SON seasons $(N=16)$. Analysis between AOD satellite-satellite retrievals revealed that none of their comparison had collocating paired data (common days greater than 5) for all the seasons of the study period. While MODIS AOD - MISR AOD was affected in SON and OMI AOD - MODIS AOD in JJA and SON, OMI AOD - MISR AOD was 
affected for the entire study period. The MODIS AOD valuation using validated ground PM measurements are similar to results drawn from other comparative in-situ PM and MODIS AOD studies (Liu et al., 2007; Filip and Stefan, 2011; Yap and Hashim, 2013; Sukitpaneenit and Oanh, 2014; Bibi et al., 2015; Kong et al., 2016). Our findings are within the acceptable range established by similar literature (Figure 6b). This reveals that MODIS is the most suited satellite PM measurement instrument for users in the Zaria metropolis, Nigeria.

\section{Conclusion}

Studies have established that satellite datasets from remote sensing of surface air quality contains a wealth of knowledge that is still being exploited, thus, the need to evaluate satellite-based pollution monitoring to specific areas or regions of the world. In limited resource environment like Nigeria, portable pollutant monitors are being embraced for air pollution monitoring. This study utilized validated MSA Altair $5 x$ gas sensor and the CWHAT200 particulate counter to evaluate the city-scale monitoring capability of selected NASA pollution monitoring instruments. The findings revealed that the MOPITT CO and MODIS $A O D$ are the better suited satellite pollution estimates for representing ground level $\mathrm{CO}$ and $\mathrm{PM}_{10}$ measurement within Zaria metropolis, Nigeria. Our city-scale evaluation of satellite pollution estimates using portable monitors were within acceptable boundary limits when compared to other similar studies that utilized the reference pollution monitoring stations. This findings pilots a fundamental issue in air pollution monitoring within the Nigerian frontier, where none has been previously carried out. We are optimistic that that our findings offers Nigeria's air quality planners with the framework of portable cost-effective pollutant monitors and satellite air pollution measurements, to mitigate the adverse impacts of air quality within its rapidly growing population and scarce air quality information.

\section{Acknowledgement}

This study is supported by the University of Pretoria postgraduate bursary and the Ahmadu Bello University, Zaria research grant to the first author. Daily day-time level 3 pollutant estimate data, were utilized for the selected satellite instruments. AIRS CO, OMI AOD, MODIS AOD were obtained from the NASA Subset wizard (SSW) website (https://disc.sci.gsfc.nasa.gov/SSW). MOPITT CO and MISR AOD were downloaded from the NASA reverb website (https://reverb.earthdata.nasa.gov). We sincerely appreciate the anonymous reviewers that helped to improve the quality of the manuscript. 


\section{References}

Adams, M.D., De Luca, P.F., Corr, D., Kanaroglou, P.S., 2012. Mobile air monitoring: measuring change in air quality in the city of Hamilton, 2005-2010. Social Indicators Research 108, 351-364. https://dx.doi.org/10.1007/s11205-012-0061-5

Adewunmi, R., Adewunmi, R., Obi, P., Odumosu, A., 2015. P15 assessment of cumulative exposures of traffic wardens to vehicular emissions in Zaria, Nigeria. Journal of Transport and Health 2(2), S71. https://dx.doi.org/10.1016/j.jth.2015.04.474

Araki, S., Yamamoto, K., Kondo, A., 2015. Application of regression kriging to air pollutant concentrations in Japan with high spatial resolution. Aerosol and Air Quality Research 15, 234-241. https://dx.doi.org/10.4209/aaqr.2014.01.0011

Asatar, G.I., Nair, P.R., 2010. Spatial distribution of near-surface CO over Bay of Bengal during winter: role of transport. Journal of Atmospheric and Solar-Terrestrial Physics 72(17), 12411250. https://dx.doi.org/10.1016/j.jastp.2010.07.025

Barret, B., Mazière, M.D., Mahieu, E., 2003. Ground-based FTIR measurements of CO from the Jungfraujoch: characterisation and comparison with in situ surface and MOPITT data. Atmospheric Chemistry and Physics 3(6), 2217-2223. https://dx.doi.org/10.5194/acp-32217-2003

Bell, M.L., Davis, D.L., 2001. Reassessment of the lethal London fog of 1952: novel indicators of acute and chronic consequences of acute exposure to air pollution. Environmental Health Perspective 109 (3), 389.

Bereznicki, S.D., Kamal, A., 2013. Observations of interference between portable particle counters and NOx monitors. Atmospheric Environment 75, 303-307. https://dx.doi.org/10.1016/j.atmosenv.2013.04.064

Bibi, H., Alam, K., Chishtie, F., Bibi, S., Shahid, I., Blaschke, T., 2015. Intercomparison of MODIS, MISR, OMI, and CALIPSO aerosol optical depth retrievals for four locations on the Indo-Gangetic plains and validation against AERONET data. Atmospheric Environment 111, 113-126. https://dx.doi.org/10.1016/j.atmosenv.2015.04.013

Buchholz, R.R., Deeter, M.N., Worden, H.M., Gille, J., Edwards, D.P., Hannigan, J.W., Jones, N.B., Paton-Walsh, C., Griffith, D.W., Smale, D., Robinson, J., 2017. Validation of MOPITT carbon monoxide using ground-based Fourier transform infrared spectrometer data from NDACC. Atmospheric Measurement Techniques 10(5), 1927-1956. https://dx.doi.org/10.5194/amt-10-1927-2017

Chai, T., Draxler, R.R., 2014. Root mean square error (RMSE) or mean absolute error (MAE)?Arguments against avoiding RMSE in the literature. Geoscience Model Development 7(3), 1247-1250. https://dx.doi.org/10.5194/gmd-7-1247-2014

Dash, I., 2016. Space-time observations for city level air quality modelling and mapping. MSc Thesis, University of Twente, The Netherlands, 80 pages.

Deeter, M.N., Emmons, L.K., Francis, G.L., Edwards, D.P., Gille, J.C., Warner, J.X., Khattatov, B., Ziskin, D., Lamarque, J.-F., Ho, S.-P., Yudin, V., Attié, J.L., Packman, D., Chen, J., Mao, D., Drummond, J.R., 2003. Operational carbon monoxide retrieval algorithm and selected results for the MOPITT instrument. Journal of Geophysical Research 108, 4399. https://dx.doi.org/10.1029/2002JD003186

Duncan, B.N., Prados, A.I., Lamsal, L.N., Liu, Y., Streets, D.G., Gupta, P., Hilsenrath, E., Kahn, R.A., Nielsen, E., Beyersdorf, A.J., Burton, S.P., Fiore, A.M., Fisherman, J., Henze, D.K., Hosteltler, C.A., Krotkov, N.A., Lee, P., Lin, M., Pawson, S., Pfister, S., Pickering, K.E., Bradley Pierce, R., Yoshida, Y., Ziemba, L.D., 2014. Satellite data of atmospheric pollution for US air quality applications: Examples of applications, summary of data end-user resources, answers to FAQs, and common mistakes to avoid. Atmospheric Environment 94, 647-662. https://dx.doi.org/10.1016/j.atmosenv.2014.05.061 
Duvall, R., Norris, G., Burke, J., Olson, D., Vedantham, R., Williams, R., 2012. Determining spatial variability in $\mathrm{PM}_{2.5}$ source impacts across Detroit, MI. Atmospheric Environment 47, 491-498. https://dx.doi.org/10.1016/j.atmosenv.2011.09.071

Efe, S.I., Efe, A.T., 2008. Spatial distribution of particulate matter (PM10) in Warri metropolis, Nigeria. The Environmentalist 28(4), 385-394. http://dx.doi.org/10.1007/s10669-007-9154-0

Engel, B., Storm, D., White, M., Arnold, J., Arabi, M., 2007. A hydrologic/water quality model application protocol. Journal of the American Water Resources Association 43(5), 1223-1236. https://dx.doi.org/10.1111/j.1752-1688.2007.00105.x

Engel-Cox, J.A., Holloman, C.H., Coutant, B.W., Hoff, R.M., 2004. Qualitative and quantitative evaluation of MODIS satellite sensor data for regional and urban scale air quality. Atmospheric Environment 38, 2495-2509. https://dx.doi.org/10.1016/j.atmosenv.2004.01.039

Engel-Cox, J., Oanh, N.T.K., van Donkelaar, A., Martin, R.V., Zell, E., 2013. Toward the next generation of air quality monitoring: particulate matter. Atmospheric Environment 80, 584-590. https://dx.doi.org/10.1016/j.atmosenv.2013.08.016

Filip, L., Stefan, S., 2011. Study of the correlation between the near-ground PM10 mass concentration and the aerosol optical depth. Journal of Atmospheric and Solar-Terrestrial Physics 73(13), 1883-1889. https://dx.doi.org/10.1016/j.jastp.2011.04.027

Fisher, J.A., Jacob, D.J., Purdy, M.T., Kopacz, M., Le Sager, P., Carouge, C., Holmes, C.D., Yantosca, R.M., Batchelor, R.L., Strong, K., Diskin, G.S., Fuelberg, H.E., Holloway, J.S., Hyer, E.J., McMillan, W.W., Warner, J., Streets, D.G., Zhang, Q., Wang, Y., Wu, S., 2010. Source attribution and interannual variability of Arctic pollution in spring constrained by aircraft (ARCTAS, ARCPAC) and satellite (AIRS) observations of carbon monoxide. Atmospheric Chemistry and Physics 10, 977-996. https://dx.doi.org/10.5194/acp-10-977-2010

Ghozikali, M.G., Mosaferi, M., Safari, G.H., Jaafari, J., 2015. Effect of exposure to O3, NO2, and SO2 on chronic obstructive pulmonary disease hospitalizations in Tabriz, Iran. Environment Science and Pollution Research 22(4), 2817-2823. https://dx.doi.org/10.1007/s11356-014$3512-5$

Gozzi, F., Della Ventura, G., Marcelli, A., 2016. Mobile monitoring of particulate matter: State of art and perspectives. Atmospheric Pollution Research 7(2), 228-234. https://dx.doi.org/10.1016/j.apr.2015.09.007

Guo, H., Wang, Y. and Zhang, H., 2017. Characterization of criteria air pollutants in Beijing during 2014-2015. Environmental Research 154, 334-344. https://dx.doi.org/10.1016/j.envres.2017.01.029

Hersey, S.P., Garland, R.M., Crosbie, E., Shingler, T., Sorooshian, A., Piketh, S., Burger, R., 2015. An overview of regional and local characteristics of aerosols in South Africa using satellite, ground, and modeling data. Atmospheric Chemistry and Physics 15(8), 4259-4278. https://dx.doi.org/10.5194/acp-15-4259-2015

Jolliffe, I.T., Stephenson, D.B., (Eds.) 2012. Forecast Verification: A Practitioner's Guide in Atmospheric Science. John Wiley and Sons, Chichester, pp. 240

Kanaroglou, P., Jerrett, M., Morrison, J., Beckerman, B., Arain, M.A., Gilbert, N.L., Brook, J.R., 2005. Establishing an air pollution monitoring network for intraurban population exposure assessment: a location-allocation approach. Atmospheric Environment 39, 2399-2409. https://dx.doi.org/10.1016/j.atmosenv.2004.06.049

Kgabi, N. A. 2014. Air quality policy and scientific research in Southern Africa. In: Longhurst, J. W. S. and Brebbia, C. A. ed. Air Pollution XX. WIT Press, Southampton, UK, pp. 151-163.

Kong, L., Xin, J., Zhang, W., Wang, Y., 2016. The empirical correlations between PM 2.5, PM 10 and AOD in the Beijing metropolitan region and the PM 2.5, PM 10 distributions retrieved by 
$\begin{array}{llll}\text { MODIS. } & \text { Environmental 350-360. }\end{array}$

https://dx.doi.org/10.1016/j.envpol.2016.05.085

Kumar, P., Morawska, L., Martani, C., Biskos, G., Neophytou, M., Di Sabatino, S., Bell, M., Norford, L., Britter, R., 2015. The rise of low-cost sensing for managing air pollution in cities. Environment International 75, 199-205. https://dx.doi.org/10.1016/j.envint.2014.11.019

Le Boennec, R., Salladarré, F., 2017. The impact of air pollution and noise on the real estate market. The case of the 2013 European Green Capital: Nantes, France. Ecological Economics 138, 82-89. https://dx.doi.org/10.1016/j.ecolecon.2017.03.030

Liou, K.N., 2002. An introduction to atmospheric radiation. 2nd ed. Academic Press, New York, pp. 350-353.

Liu, J., Man, Y., Liu, Y., 2014. Temporal variability of $\mathrm{PM}_{10}$ and $\mathrm{PM}_{2.5}$ inside and outside a residential home during 2014 Chinese spring festival in Zhengzhou, China. Natural Hazards, 73(3), 2149-2154. https://dx.doi.org/10.1007/s11069-014-1157-9

Liu, Y., Franklin, M., Kahn, R., Koutrakis, P., 2007. Using aerosol optical thickness to predict ground-level PM 2.5 concentrations in the St. Louis area: a comparison between MISR and MODIS. Remote Sensing of the Environment 107(1), 33-44. https://dx.doi.org/10.1016/j.rse.2006.05.022

Llanes, S., 2016. How to calculate time-weighted average (TWA). $26^{\text {th }}$ Annual California Industrial Hygiene Council (CIHC) Conference, San Diego, http://www.thecohengroup.com/article/calculate-time-weighted-average-twa/, accessed in October 2017.

Marais, E.A., Chance, K., 2015. A geostationary air quality monitoring platform for Africa. Clean Air Journal 25(1), 40-45. https://dx.doi.org/10.17159/2410-972X/2015/v25n1a3

Marais, E.A., Jacob, D.J., Wecht, K., Lerot, C., Zhang, L., Yu, K., Kurosu, T.P., Chance, K., Sauvage, B., 2014. Anthropogenic emissions in Nigeria and implications for atmospheric ozone pollution: A view from space. Atmospheric Environment 99, 32-40. https://dx.doi.org/10.1016/j.atmosenv.2014.09.055

Marey, H.S., Hashisho, Z., Fu, L., Gille, J., 2015. Spatial and temporal variation in CO over Alberta using measurements from satellites, aircraft, and ground stations. Atmospheric Chemistry and. Physics 15(7), 3893-3908. https://dx.doi.org/10.5194/acp-15-3893-2015

McCuen, R.H., Knight, Z., Cutter, A.G., 2006. Evaluation of the Nash-Sutcliffe efficiency index. Journal of Hydrologic Engineering 11(6), 597-602.

McMillan, W.W., Barnet, C., Strow, L., Chahine, M.T., McCourt, M.L., Warner, J.X., Novelli, P.C., Korontzi, S., Maddy, E.S., Datta, S., 2005. Daily global maps of carbon monoxide from NASA's Atmospheric Infrared Sounder. Geophysical Research Letters 32, L11801. https://dx.doi.org/10.1029/2004GL021821

Mead, M.I., Popoola, O.A.M., Stewart, G.B., Landshoff, P., Calleja, M., Hayes, M., Baldovi, J.J., McLeod, M.W., Hodgson, T.F., Dicks, J., Lewis, A., Cohen, J., Baron, R., Saffell, J.R., Jones, R.L., 2013. The use of electrochemical sensors for monitoring urban air quality in low-cost, high-density networks. Atmospheric Environment 70, 186-203. http://dx.doi.org/10.1016/j.atmosenv.2012.11.060

Miri, M., Derakhshan, Z., Allahabadi, A., Ahmadi, E., Conti, G.O., Ferrante, M., Aval, H.E., 2016. Mortality and morbidity due to exposure to outdoor air pollution in Mashhad metropolis, Iran. The AirQ model approach. Environmental Research 151, 451-457. https://dx.doi.org/10.1016/j.envres.2016.07.039

Mishra, R.K., Joshi, T., Goel, N., Gupta, H., Kumar, A., 2015. Monitoring and analysis of PM10 concentration at Delhi Metro construction sites. International Journal of Environment and Pollution 57(1-2), 27-37. https://doi.org/10.1504/IJEP.2015.072111 
NASA (National Aeronautics and Space Administration), 2017. https://www.nasa.gov/open/researchaccess/nasa-data-portal, accessed in March 2017.

Neophytou, M., Gowardan, A., Brown, M.J., 2011. An inter-comparison of three urban wind models using Oklahoma City Joint Urban 2003 wind field measurements. Journal of Wind $\begin{array}{llll}\text { Energy and Industrial } & \text { Aerodynamics }\end{array}$ https://dx.doi.org/10.1016/j.jweia.2011.01.010

Orogade, S.A., Owoade, K.O., Hopke, P.K., Adie, D.B., Ismail A., Okuofu, C.A., 2016. Source apportionment for fine and coarse particulate matter in industrial areas of Kaduna, northern Nigeria. Aerosol and Air Quality Research 16, 1179-1190. https://dx.doi.org/10.4209/aaqr.2015.11.0636

Ren, M., Li, N., Wang, Z., Liu, Y., Chen, X., Chu, Y., Li, X., Zhu, Z., Tian, L., Xiang, H., 2017. The short-term effects of air pollutants on respiratory disease mortality in Wuhan, China: comparison of time-series and case-crossover analyses. Scientific Reports. 7, 40482. https://dx.doi.org/10.1038/srep40482

Rinsland, C.P., Luo, M., Logan, J.A., Beer, R., Worden, H., Kulawik, S.S., Rider, D., Osterman, G., Gunson, M., Eldering, A., Goldman, A., Shephard, M., Clough, S.A., Rodgers, C., Lampel, M., Chiou, L., 2006. Nadir measurements of carbon monoxide distributions by the Tropospheric Emission Spectrometer instrument onboard the Aura Spacecraft: overview of analysis approach and examples of initial results. Geophysical Research Letters 33, L22806. https://dx.doi.org/10.1029/2006GL027000

Schaap, M., Apituley, A., Timmermans, R.M.A., Koelemeijer, R.B.A., de Leeuw, G., 2009. Exploring the relation between aerosol optical depth and PM2.5 at Cabauw, the Netherlands. Atmospheric Chemistry and Physics 9, 909-925. https://dx.doi.org/10.5194/acp-9-909-2009

Schäfer, K., Harbusch, A., Emeis, S., Koepke, P., Wiegner, M., 2008. Correlation of aerosol mass near the ground with aerosol optical depth during two seasons in Munich. Atmospheric Environment 42(18), 4036-4046. https://dx.doi.org/10.1016/j.atmosenv.2008.01.060

Shibata, T., Wilson, J.L., Watson, L.M., Nikitin, I.V., La Ane, R., Maidin, A., 2015. Life in a landfill slum, children's health, and the millennium development goals. Science of the Total Environment 536, 408-418. https://dx.doi.org/10.1016/j.scitotenv.2015.05.137

Snyder, E.G., Watkins, T., Solomon, P., Thoma, E., Williams, R., Hagler, G., Shelow, D., Hindin, D., Kilaru, V., Preuss, P., 2013. The changing paradigm of air pollution monitoring. Environmental Science and Technology 47, 11369-11377. https://dx.doi.org/10.1021/es4022602

Streets, D.G., Canty, T., Carmichael, G.R., de Foy, B., Dickerson, R.R., Duncan, B.N., Edwards, D.P., Haynes, J.A., Heinze, D.K., Houyoux, M.R., Jacob, D.J., Krotkov, N.A., Lamsal, L.N., Liu, Y., Lu, Z., Martin, R.V., Pfister, G.G. Pinder, R.W., Salawitch, R.J., Wecht, K.J., 2013. Emissions Estimation from Satellite Retrievals: A Review of Current Capability. Atmospheric Environment 77, 1011-1042. https://dx.doi.org/10.1016/j.atmosenv.2013.05.051

Sukitpaneenit, M., Oanh, N.T., 2014. Satellite monitoring for carbon monoxide and particulate matter during forest fire episodes in Northern Thailand. Environmental Monitoring and Assessment 186(4), 2495-2504. https://dx.doi.org/10.1007/s10661-013-3556-x

The Economist, 2017. Nigeria: Africa's new number one, 2014. http://www.economist.com/news/leaders/21600685-nigerias-suddenly-supersized-economyindeed-wonder-so-are-its-still-huge, accessed in February 2017.

Tian, B., Manning, E., Fetzer, E., Olsen, E., Wong, S., Susskind, J., Iredel, L., 2014. AIRS/AMSU/HSB Version 6 Level 3 Product User Guide. http://disc.sci.gsfc.nasa.gov/AIRS/documentation/v6_docs/v6releasedocs1/V6_L3_User_Guid e.pdf, accessed in June 2016. 
UN (United Nations) Economic and Social Affairs, 2017. World Population Prospects: the 2015 Revision. New York. http://esa.un.org/unpd/wpp/, accessed in 2017.

Vollmer, B., 2010. AIRS Data and Services at the GSFC Earth Sciences Data and Information Services Centre (GES DISC). http://airs.jpl.nasa.gov/documents/science_team_meeting_archive/2010_11/slides/Vollmer.pdf , accessed in June 2016.

WHO (World Health Organization), 2016. Global urban ambient air pollution database update, 2016.

http://www.who.int/phe/health_topics/outdoorair/databases/WHO_AAP_database_May2016_v 3web.xlsx?ua=1, accessed in September 2017.

WHO (World Health Organization), 2017. Evolution of WHO air quality guidelines. Past, present and future,] http://www.euro.who.int/_data/assets/pdf_file/0019/331660/Evolution-airquality.pdf, accessed in September 2017.

Yap, X.Q., Hashim, M., 2013. A robust calibration approach for PM10 prediction from MODIS aerosol optical depth. Atmospheric Chemistry and Physics 13(6), 3517-3526. https://dx.doi.org/10.5194/acpd-12-31483-2012

Yazdi, M.N., Delavarrafiee, M., Arhami, M., 2015. Evaluating near highway air pollutant levels and estimating emission factors: Case study of Tehran, Iran. Science of the Total Environment 538, 375-384. https://dx.doi.org/10.1016/j.scitotenv.2015.07.141

Yoshizaki, K., Brito, J.M., Silva, L.F., Lino-dos-Santos-Franco, A., Frias, D.P., Silva, R.C., AmatoLourenço, L.F., Saldiva, P.H., Tibério, I.D., Mauad, T., Macchione, M., 2017. The effects of particulate matter on inflammation of respiratory system: Differences between male and female. Science of the Total Environment 586, 284-295. https://dx.doi.org/10.1016/j.scitotenv.2017.01.221

Zhang, L., Jiang, H., Lu, X., Jin, J., 2016. Comparison analysis of global carbon monoxide concentration derived from SCIAMACHY, AIRS, and MOPITT. International Journal of Remote Sensing 37(21), 5155-5175. https://dx.doi.org/10.1080/01431161.2016.1230282 